\title{
PROGNOSTIC FACTORS INFLUENCING MORBIDITY AND MORTALITY IN ESOPHAGEAL CARCINOMA
}

\author{
Andrea Cariati, Alessandro Casano, Antonello Campagna, Erminio Cariati and \\ Gianluigi Pescio
}

RHCFAP/3093

CARIATI A et al. - Prognostic factors influencing morbidity and mortality in esophageal carcinoma. Rev. Hosp. Clín. Fac.

Med. S. Paulo 57(5):201-204, 2002.

PURPOSE: In 1980, operative mortality for esophageal resection was 29\%. Over the last 15 years, technical and critical care improvements contributed to the reduction of postoperative mortality rate to $8 \%$. The aim of this study is to analyze retrospectively the role of different factors (surgical procedure, stage of the disease, and anesthetic risk) on the postoperative mortality of 63 patients that underwent esophagectomy with gastric interposition for cancer.

METHODS: Seventy-two patients underwent esophagectomy. The stomach was the esophageal substitute in 63 cases. Surgical procedures included transthoracic esophagectomy in 49 patients and transhiatal esophagectomy in 14 cases. Among the 49 transthoracic esophagectomy patients, there were 18 patients with a high anesthetic risk (ASA III). Among the patients that underwent transhiatal esophagectomy, there were 10 patients with a high anesthetic risk (ASA III).

RESULTS: The operative mortality rate was $14 \%(2 / 14)$ in transhiatal esophagectomy group and 22\% (11/49) in transthoracic esophagectomy group $(P=\mathrm{ns})$. The postoperative mortality of patients with a high anesthetic risk (ASA III) was $47 \%(8 / 17)$ after transthoracic esophagectomy and 10\% (1/10) after transhiatal esophagectomy $(P<0.05)$.

DISCUSSION: In our experience, the operative mortality was nearly $18 \%$ (16.6\% after transhiatal esophagectomy and $20.8 \%$ after transthoracic esophagectomy). Among the patients with a high anesthetic risk (ASA III) that underwent surgery, the postoperative mortality was significantly lower after transhiatal esophagectomy (10\%) compared to transthoracic esophagectomy $(47 \%)(P<0.05)$.

DESCRIPTORS: Esophageal carcinoma. Transhiatal esophagectomy. Transthoracic esophagectomy. Prognostic factors. Anesthetic risk.

\section{INTRODUCTION}

Esophageal carcinoma has a dismal prognosis. The 5-year survival rate of patients with esophageal carcinoma who underwent surgery has been reported to be only $20 \%{ }^{1-3}$. In a 1980 review article by Earlam and CunhaMelo, more than 32,000 esophageal resections had a collective operative mortality of $29 \%{ }^{4}$. Over the past 15 years, technical and critical care improvements have contributed to the reduction of reported postoperative mortality rates from $29 \%{ }^{4}$ to $4 \%-12 \%{ }^{2,5-13}$. The aim of this study is to analyze ret- rospectively the role of different factors (surgical procedure, stage of the disease, and anesthetic risk) on the postoperative mortality, and the morbidity of 63 patients who underwent esophagectomy with gastric interposition for cancer from 1978 to 2000.

\section{MATERIALS AND METHODS}

Between 1978 and 2000, 95 patients with esophageal carcinoma were

From the Institute of Surgical Clinic, Genoa University; School of General Surgery, University of Genoa and Department of General Surgery, Imperia General Hospital. admitted to our Institute. Among them, 72 patients ( 58 men, mean age 65.5 years; 14 women, mean age 62.5 years) underwent esophagectomy (resection rate, $76 \%$ ). Patients who had jejunum (7 patients) or colon (2 patients) interposition were excluded. Stomach was the esophageal substitute in 63 cases.

Surgical procedures included transthoracic esophagectomy (TTE) according to Lewis ${ }^{14}$ in 49 patients and transhiatal esophagectomy (THE) according to Orringer ${ }^{15,16}$ and Akiyama ${ }^{17-}$ ${ }^{21}$ in 14 cases.

The 49 patients that underwent TTE had spinocellular carcinoma in 42 cases 
and adenocarcinoma in 7 cases. Tumor locations were cervical esophagus $4 \%$ ( 2 patients), upper thoracic esophagus $4 \%$ (2 patients), midthoracic esophagus $31 \%$ (15 patients), and inferior thoracic esophagus $61 \%$ (30 patients). TTE patients had an extensive 2-field en bloc lymphadenectomy. Cervical lymphadenectomy was performed only for cervical and upper thoracic esophageal tumors.

Tumor stages were stage I (N0) in 2 patients, stage IIA (NO) in 16 patients, stage IIB (N1) in 6 patients, and stage III (N1) in 25 patients. Thirty-one patients had lymph nodal metastases.

Among the 49 TTE patients, there were 18 patients $(37 \%)$ with a high anesthetic risk $\left(\mathrm{ASA}^{3} \mathrm{III}\right)^{22}$.

Of the 14 patients that underwent THE, 13 had a spinocellular carcinoma and 1 had an adenocarcinoma. Tumor locations were cervical esophagus in $43 \%$ (6 cases), upper thoracic esophagus $7 \%$ (1 patient), middle thoracic esophagus $21 \%$ ( 3 cases), and inferior thoracic esophagus 29\% (4 patients). Lymph node dissection of the lower mediastinum and of the abdomen, including the region of the left gastric and celiac arteries, was performed during THE. Cervical lymph node dissection was performed for the cervical and upper thoracic tumors. Tumor stages were stage I (N0) in 2 patients, stage IIA (N0) in 3 patients, stage IIB (N1) in 3 patients, and stage III (N1) in 6 patients. Nine patients had lymph nodal metastases. The organ used for the substitution of the esophagus was the Akiyama gastric tube in all the cases. Among the patients that underwent THE, there were 10 patients with a high anesthetic risk (ASA $\left.{ }^{3} \mathrm{III}\right)$.

Concerning technique, we performed all the cervical anastomoses for the THE procedures and 30/49 of the intrathoracic anastomoses for the TTE procedures using 1 seromuscular interrupted suture of propylene $3 / 0$; we used the EEA stapler in the other 19 cases of TTE.

Discrete data were compared using the Chi square test and the Fisher ex- act test. Continuous data were compared using the Student's $t$ test. The log-rank test of Mantel was used to compare survival curves ${ }^{23}$.

\section{RESULTS}

The 30-day operative mortality rates were $16.6 \%(2 / 14)$ for THE and $20.8 \%(11 / 49)$ for TTE $(P=n s)$. Variables related to age, gender, and histotype are listed in table 1.

Postoperative morbidity (bronchopneumonitis, pleural effusion, anastomotic leakage, recurrent laryngeal nerve paralysis, and chylothorax) was $54 \%(25 / 49)$ for TTE and 57\% (8/14) for THE $(P=\mathrm{ns})$. The transhiatal approach appeared to have a higher incidence of recurrent laryngeal nerve injuries (33\%) $(P \leq .01)$.

Major complications were 8 partial or total anastomotic leaks ( 2 after THE and 6 after TTE, $P=\mathrm{ns}$ ), 25 respiratory complications (6 after THE and 19 after TTE, $P=\mathrm{ns}$ ), 1 chylothorax after TTE, and 4 recurrent laryngeal nerve paralysis after THE $(P £ 0.01)$ (Table 2).

The postoperative period of hospitalization was 24 days (+-6.45 SD) for the THE patients and 31. 39 days (+9.3 SD) for the TTE patients $(P<0.05)$.

The incidence of anastomotic leakage was $14 \%(2 / 14)$ after THE and $12 \%(6 / 49)$ after TTE $(P=n s)$. The mortality for anastomotic leakage after THE was 50\% (1/2), and 80\% (5/6) after TTE $(P<0.05)$. The survival rate for cases with cervical fistula after THE (50\%) was higher than the survival rate for cases of intrathoracic fistula after TTE $(20 \%)(P<0.05)$.

Among the TTE-treated patients, the incidence of anastomotic leakage was $10 \%$ (3/30) after manual suture and $16 \%(3 / 19)$ after mechanical suture. $(P=\mathrm{ns})$. The incidence of anastomotic leakage after manual suture was $14 \%(2 / 14)$ for the THE group, and $10 \%(3 / 30)$ after manual suture for the TTE group $(P=\mathrm{ns})$.

The postoperative mortality of patients with a high anesthetic risk (ASA $\geq$ III) was $44 \%$ (8/17) after TTE and $10 \%(1 / 10)$ after THE $(P<0.05)$.

Five-year survival rates were $17 \%$ for TTE and $8 \%$ for THE $(P=\mathrm{ns})$, and $28.5 \%$ of N0 patients and $6 \%$ of N+ patients $(P<0.025)$. The 5-year survival curves of the patients in relationship to the presence or the absence of lymph nodal metastases have been previously reported ${ }^{24}$.

\section{DISCUSSION}

Over the past few years, technical and critical care improvements have reduced the reported postoperative mortality rate for patients undergoing resec-

Table 1 - Age, gender, and histotype of patients that underwent TTE or THE.

\begin{tabular}{llll}
\hline & TTE & THE & $P$ value \\
\hline Age & 63 & 61 & n.s. \\
Gender & 40 males/9 females & 11 males/3 females & n.s. \\
$\begin{array}{l}\text { Histotype (squamous/ } \\
\text { adenoK) }\end{array}$ & $42 / 7$ & $13 / 1$ & n.s. \\
\hline
\end{tabular}

Table 2 - Mayor complications: anastomotic leak, respiratory complications, chylothorax, recurrent laryngeal nerve paralysis.

\begin{tabular}{llll}
\hline & TTE & THE & $P$ value \\
\hline Anastomotic leakage & $6 / 49$ & $2 / 14$ & n.s. \\
Respiratory complications & $19 / 49$ & $6 / 14$ & n.s. \\
Chylothorax & $1 / 49$ & $0 / 14$ & n.s. \\
Recurrent laryngeal nerve injuries & $0 / 49$ & $4 / 14$ & $P<0.05$ \\
\hline
\end{tabular}


tion of esophageal cancer from $29 \%{ }^{4}$ to $4 \%-12 \%{ }^{2,5-13}$, and the 5-year survival rate has improved from $3 \%-5 \%{ }^{4}$ to $20 \%{ }^{1,2,3}$. In our experience, the 30-day operative mortality was nearly $18 \%$ (16.6\% after THE and $20.8 \%$ after TTE), and there was not a statistically significant difference between the two procedures. An extensive review of the literature revealed that other authors ${ }^{2}$ report a 30-day mortality of $6.3 \%$ for THE and $9.5 \%$ for TTE; TTE had the higher postoperative mortality rate.

Among the patients with a high anesthetic risk ( $\mathrm{ASA}^{3} \mathrm{III}$ ) that underwent surgery, the postoperative mortality was significantly lower after THE than after TTE. It should be noted that THE represents the best surgical option for patients with esophageal carcinoma and high anesthetic risk because it is associated with reduced surgical trauma, incidence of respiratory distress, and length of postoperative stay in hospital. Other authors report similar results ${ }^{2,3,12}$.

The postoperative morbidity was very similar for the 2 surgical procedures. The transhiatal approach appeared to have a higher incidence of recurrent laryngeal nerve injuries. The incidence of anastomotic leakage is slightly higher in the THE group, but the survival in case of cervical fistula after THE was better than the survival in the case of intrathoracic fistula after TTE. The worst prognosis concerning intrathoracic fistula is probably secondary to the mediastinitis following the anastomotic leakage after TTE. In these cases, mediastinal drainage can be introduced after mediastinoscopy. Anastomotic leaks that occur after THE tend to have a more benign course because infection and fistula can be more easily managed.

There was not a difference in the incidence of anastomotic leakage after manual or mechanical anastomoses for TTE.

The 5-year survival rates were significantly higher in patients without lymph nodal metastases. In a retrospective study, Japanese authors ${ }^{25,26}$ reported a better 5year survival after extensive collothoraco-abdominal (3-field) dissection, in particular for stage 0 and stage IV carcinoma of the upper third of the thoracic esophagus $^{26}$. Conversely, in patients with carcinoma of the lower third of the esophagus with abdominal lymph nodal metastases, 3-field dissection was not associated with improved 5-year survival rates $^{27}$. In western countries, surgeons prefer to use preoperative radio- or chemotherapy because they consider esophageal carcinoma to be a disseminated disease ${ }^{28}$. Prospective studies ${ }^{12,13}$ did not demonstrate a significant differ- ence in the survival rates of patients treated by TTE with systematic 2-field en bloc lymphadenectomy or of those treated by THE. These results stress the importance of a diagnosis of the esophageal cancer and the relative necessity of an extended lymph node dissection; it follows that patients with a low anesthetic risk (ASA < III) must be treated by TTE or by THE, and may eventually be treated with video-assisted thoracic lymph node dissection or with mediastinoscopy ${ }^{29}$. In the past few years, treatment of esophageal carcinoma by video-assisted thoracoscopy (VATS) alone did not seem to be possible because of the length of the operation time (10 hours) ${ }^{30}$. However, in a recent study ${ }^{31}$, minimally invasive esophagectomy had a shorter operative time and less blood loss than THE and TTE.

We suggest that: i) THE represents the best surgical option in patients with a high anesthetic risk ( $\left.\mathrm{ASA}^{3} \mathrm{III}\right)$ because it reduces postoperative mortality significantly; ii) the long-term results are significantly correlated with the presence or the absence of lymph nodal metastases. Enlarged mediastinal lymphadenectomy allows the staging of the disease exactly, but we do not find that the more radical procedure (TTE) results in longer survival.
CARIATI A e col. - Fatores prognósticos influenciando a mortalidade em esofagectomia. Rev. Hosp. Clín. Fac. Med. S. Paulo 57(5):201-204, 2002.

OBJETIVO: Nos últimos 15 anos, melhorias técnicas contribuíram para a redução da taxa de mortalidade pósoperatória de 29 para $8 \%$. O objetivo deste estudo é analisar retrospectivamente o papel de diferentes fatores na mortalidade pós-operatória de 63 pacientes submetidos a esofagectomia para tratamento de câncer.

MÉTODOS: Sessenta e três pacientes foram submetidos a esofagectomia com utilização do estômago como substituto. Os procedimentos cirúrgicos incluíram esofagectomia transtorácica em 49 pacientes e esofagectomia trans-hiatal em 14 casos. Entre os 49 pacientes de esofagectomia transtorácica haviam $18(37 \%)$ com risco anestésico elevado (ASA $\geq$ III). Quatorze pacientes foram submetidos a esofagectomia trans-hiatal.

RESULTADOS: A mortalidade operatória foi de $14 \%$ na esofagectomia trans-hiatal e $22 \%$ na esofagectomia transtorácica $(\mathrm{p}=\mathrm{ns})$. A mortalidade dos pacientes com risco anestésico elevado foi de $47 \%$ após esofagectomia transtorácica e $10 \%$ após esofagectomia trans-hiatal ( $\mathrm{p}<0,05)$.

DISCUSSÃO: Em nossa experiên- 
cia, a mortalidade foi de quase $18 \%$ e $22 \%$ após esofagectomia transtorácica. Entre os pacientes com risco anestésico elevado que se submeteram à operação, a mortalidade pós-operatória foi significativamente mais baixa após a esofagectomia trans-hiatal (10\%) comparativamente à esofagectomia transtorácica $(47 \%)(\mathrm{p}<0,05)$.
DESCRITORES: Carcinoma de esôfago. Esofagectomia trans-hiatal. Esofagectomia transtorácica. Fatores prognósticos. Risco anestésico.

\section{REFERENCES}

1. WATSON A - Operable esophageal cancer: current results from the west. Word J Surg 1994; 18: 361-366.

2. RINDANI R, MARTIN CJ, COX MR - Transhiatal versus IvorLewis oesophagectomy: is there a difference? Aust $\mathbf{Z}$ Z J Surg 1999; 69: 187-194.

3. BOYLE MJ, FRANCESCHI D., LIVINGSTONE AS - Transhiatal versus transthoracic esophagectomy: complication and survival rates. Am J Surg 1999; 65: 1137-41.

4. EARLAM R, CUNHA-MELO JR - Esophageal squamous cell carcinoma. A critical review of surgery. Br J Surg 1980; 67: 381 .

5. SABANATHAN S, HASMINI H, PRADHAN GN - Transhiatal oesophagectomy in the management of carcinoma of the thoracic oesophagus. J R Coll Surg Edinb 1988; 33: 192-195.

6. FINLEY RJ, INCULET RI - The results of esophagogastrectomy without thoracotomy for adenocarcinoma of the esophagogastric junction. Ann Surg 1989; 210: 535-543.

7. HANKINKS JR, ATTAR S, COUGHLIN TR et al. - Carcinoma of the esophagus: A comparison of transhiatal and transthoracic resection for carcinoma of the thoracic esophagus. Am J Surg 1989; 158: 414-419.

8. SKINNER DB, LITTLE AG, FERGUSON MK et al. - Selection of operation for esophageal cancer based on staging. Ann Surg 1986; 204: 319 .

9. WATSON A - A study of the quality and duration of survival following resection, endoscopic intubation and surgical intubation in oesophageal carcinoma. Br J Surg 1982; 69: 585.

10.MCKEOWN KC - The surgical treatment of carcinoma of the esophagus. J R Coll Surg Edinb 1985; 301: 1.

11.ORRINGER MB, MARSHALL B, IANNETTONI MD - Transhiatal esophagectomy: clinical experience and refinements. Ann Surg 1999; 230: 400-3.

12.CHU KM, LAW S.Y, FOK M, WONG J - A prospective randomized comparison of transhiatal and transthoracic resection for lowerthird esophageal carcinoma. Am J Surg 1997; 174: 320-4.

13.HORSTMANN O, VERREET PR, BECKER H, OHMANN C, ROHER HD - Transhiatal oesophagectomy compared with transthoracic resection and systematic lymphadenectomy for the treatment of oesophageal cancer. Eur J Surg 1995; 161: 447-67.

14.LEWIS I - The surgical treatment for carcinoma of the oesophagus with special reference to a new operation for growth of the middle third. Br J Surg 1946; 34: 18-29.

15.ORRINGER MB, ORRINGER JS - Esophagectomy without thoracotomy: a dangerous operation? J Thorac Cardiovasc Surg 1983; 85: 72-80.

16.ORRINGER MB - Transthoracic versus transhiatal esophagectomy: what differences does it make? Ann Thorac Surg 1987; 44: 116-118.
17.AKIYAMA H, SATO Y, TAKASHASHI F - Immediate pharyngogastrostomy following total esophagectomy by blunt dissection. Jpn J Surg 1971; 1: 225-232.

18.AKIYAMA H, KOGURS T - Esophageal reconstruction for stenosis due to diffuse scleroderma. Utilizing blunt dissection of esophagus. Arch Surg 1973; 107: 470.

19.AKIYAMA H, HIYAMA M - A simple esophageal bypass operation by the high gastric division. Surgery 1974; 75: 674-681.

20.AKIYAMA H, MIYAZONO H, TSURUMARU M, HASHIMOTO C, KAWAMURA T - Use of the stomach as an esophageal substitute. Ann Surg 1978; 188: 606-610.

21.CARIATI E, PELLICCI R, TAVIANI M et al. - Esophagectomy according to Akiyama. Prospectives and therapeutic possibilities. Chirurgia Toracica 1984; 37: 1-8.

22.American Society of Anesthesiologists - New classification of physical status. Anesthesiology 1963; 23: 11.

23.PETO R, PIKE MC ARMITAGE P et al. - Design and analysis of randomized trials requiring prolonged observation of each patient. Br J Cancer 1977; 35: 1-39.

24.CARIATI A, CETTA F, TAVIANI et al. - Preoperative radiotherapy in esophageal carcinoma. Journal of Chemother 1996; 8 (4): 80-81.

25.AKIYAMA H, TSURUMARU M, UDAGAWA H, KAJIYAMA Y Radical lymph node dissection for cancer of the thoracic esophagus. Ann Surg 1994; 20: 364-372.

26.TSURUMARU M, AKIYAMA H, UDAGAWA H et al. - Evaluation of the collo-thoraco-abdominal dissection for the intrathoracic esophageal carcinoma. Nippon Geka Gakkai Zasshi 1989; 90: $1612-5$.

27.TSURUMARU M, UDAGAWA H, KAJIYAMA Y et al. - Rational extent of lymph node dissection for carcinoma of the lower third of the thoracic esophagus of T2 or T3 stage with abdominal lymph node metastasis. Nippon Geka Gakkai Zasshi 1997; 98: $755-60$.

28.UDAGAWA H, TSURUMARU M, AKIYAMA H - Difference between Japan and western countries in the treatment strategy for esophageal cancer. Gan To Kagaku Ryoho 1998; 25: 1111-7.

29.KOIDE N, HIRAGURI M, NISHIO A et al. - Three elderly patients with lower esophageal cancer successfully treated by transhiatal esophagectomy assisted by mediastinoscopy. Surg Laparose Endosc Percutan Tech 2000; 10: 391-5.

30.PERACCHIA A, FUMAGALLI M, ROSATI R et al. - Minimally invasive surgery for disease of the esophagus. Int J Surg Sci 1994; 1: 19-21.

31.NGUYEN NT, FOLLETTE DM, WOLFE BM et al. - Comparison of minimally invasive esophagectomy with transthoracic and transhiatal esophagectomy. Arch Surg 2000; 135: 920-5.

Received for publication on June 20, 2001 